\title{
A Worldwide Perspective on Viticultural Zoning
}

\author{
E. Vaudour ${ }^{1}$ and A.B. Shaw ${ }^{2}$ \\ (1) Institut National Agronomique Paris-Grignon, UMR INRA/INA P-G “Environnement et Grandes Cultures” - Equipe Sol-DMOS, \\ Centre de Grignon, Avenue Lucien Brétignières, 78850 Thiverval-Grignon, France. E-mail: Emmanuelle.Vaudour@grignon.inra.fr \\ (2) Brock University, Department of Geography, St. Catharines, ON, L2S 3A1, Canada
}

Submitted for publication: April 2005

Accepted for publication: September 2005

Key Words: terroir, viticulture, zoning methods

This article reviews viticultural zoning concerns and issues, from a worldwide perspective. The needs of the everexpanding international wine market, and thus zoning objectives, have seen significant changes in recent years. Consequently, more countries and individual wine-producing regions have been involved in zoning studies. Although many of these studies were initiated in Europe, zoning needs reach far beyond the countries endowed with centuries-old viticultural history. The demarcation of registered designations of origin or protected geographical indications is one of the most obvious zoning aims. Viticultural zoning originated in the XIX ${ }^{\text {th }}$ century in Europe, but is now widely applied in even the most recent emerging wine-growing countries of the New World. Other important zoning aims, not necessarily related to demarcating operations, often involve segmenting a vineyard territory into homogeneous units for pest management, land division, vineyard-restructuring operations, harvestquality management or site selection for new vineyards. The homogeneous units obtained through viticultural zoning are frequently referred to as 'terroirs'. However, their spatial scale and the qualitative and quantitative methods of analysis may vary greatly, depending on the individual authors and the characteristics of the vinegrowing region, and consequently it is difficult to make international comparisons. Viticultural zoning studies can be divided broadly into two main approaches: the first approach is based largely on the geographic differentiation of wine, grape, or grapevine characteristics, while the second approach focuses on the geographical differentiation of land capability or vineyard suitability studies in which soil and climate are normally the key environmental variables used with varying degrees of importance. Although viticultural zoning is not always synonymous with mapping and spatial analysis, this practice is changing due to the enhanced use of geomatics. For example, digital mapping methods and remote sensing techniques have revolutionized viticultural zoning on all levels, ranging from the single plot to the regional level. On the field or local scale, the suitability approaches may include precision viticulture, which is mostly directed towards an understanding of grapevine ecophysiological functioning. On the regional or global scale, suitability approaches may be oriented towards the characterisation of broad geographical patterns of land use. The challenge with the different approaches is to compare the results derived at the regional level with those of the sample sites on the local scale. This paper provides some examples of the various approaches that are likely to enable zoning comparisons at the various spatial scales, including the international level.

The year 1996, in Angers (France), marked one of the earliest international events that focused on the identification and study of 'terroirs' and the evaluation of their relative importance worldwide. This event was the first international conference, entitled 'Viticultural Terroirs: Concept, Product and Valorization', organised by the INRA agricultural research centres of both Angers and Montpellier. Similar conferences followed in Siena (Italy) in 1998, in Tenerife (Spain) in 2000, and in Avignon (France) in 2002. These conferences revealed undoubtedly the pre-eminence of European studies on the subject of 'terroir'. However, it was also clearly evident that younger viticultural countries had begun to undertake various studies, as discussed at the Joint International Conference on Viticultural Zoning in Cape Town, South

\begin{abstract}
Africa, the first of its kind outside of Europe. As in Tenerife and Avignon, it was aimed at viticultural zoning. Viticultural zoning mainly refers to 'terroir', which is defined as a spatial and temporal entity for the production of grapes and/or wine that is characterised by the interaction between homogeneous or dominant features of soil, climate and topography at a given scale, as well as biological (variety and rootstock) and human (social, historical experience and winemaking) factors (Vaudour, 2003). Because the terroir notion integrates many human and environmental factors, it is unlikely that every vineyard in the world can possess the same combination of characteristics. Furthermore, the wide range of applications, definitions and methodological approaches add to the complexity of this notion.
\end{abstract}


The aim of this paper is fourfold. Firstly, it defines, and discusses viticultural zoning and the various aims that underlie zoning studies. Secondly, it describes the main wine-producing regions and countries that are involved in zoning studies. Thirdly, it elaborates on the zoning materials and methodological approaches used worldwide. It finally discusses recent trends in zoning methods.

\section{Viticultural Zoning and Aims}

\section{Defining Viticultural Zoning}

The term 'zoning' refers to planning and delimiting the distribution of a particular agricultural operation in a given territory into zones for which land use conditions are specified. For wine producers or professional organizations, viticultural zoning pertains to the spatial characterisation of zones that are likely to produce grapes or wines of similar compositions, while enabling operational decisions to be implemented at the various production stages (Vaudour, 2003). Such zones are often named 'terroirs' or 'terroir units'. Whether it is traditional viticulture or pioneering viticulture, every winegrowing space is individualised by boundaries. Some demarcations are pre-established, whereas others need to be determined. Not all zoning requires the delineation of geographical boundaries, especially where the latter are already defined in the form of administrative units or farming plots that at least coincide conceptually with the boundaries characterising the phenomenon. Zoning is associated with output documents normally in the form of maps. Provided boundaries are already available, spatial characterisation is thus made at a basic level, for example by using or merging demarcated boundaries. However, in order for the zones that are defined to better meet the winemaker's or technical adviser's requirements, cartographic methods and spatial modelling are preferable for viticultural zoning (Burrough, 1986; Legros, 1996; Girard and Girard, 2003).

\section{Zones Versus 'Terroir'}

Before discussing viticultural zoning from a worldwide perspective, it is necessary to emphasise a lexical debate resulting from the history of zoning or terroir-related studies that emerged between the terms 'zones' and 'terroir'. In centuries-old viticultural countries, marked attention has always been paid to the influence of vineyard conditions on the quality of grapes and their distinctive characteristics, an influence that is normally embodied in the French notions of 'terroir' (Falcetti, 1994; Bohmrich, 1996; Salette et al., 1998; Wilson, 1998; Hancock, 1999; Vaudour, 2002). With respect to grape and/or wine, 'terroir' can be defined as a spatial and temporal entity that is characterised by homogeneous or dominant attributes of the soil landscape and climate at given spatial and temporal scales within a territory based on social and historical experiences and technical choices (Vaudour, 2003). European viticulture shares the conviction of the importance of human/historical aspects, such as empirical knowledge/memory along with historical and social heritage. Because of its cultural inheritance, French viticulture was confronted with the difficult and paradoxical reconciliation of the terroir myth with terroir rationalisation. In addition to the cultural (subjective) linkage existing between terroir and human aspects, objective terroir criteria are not easy to select and manage. In order to avoid any lexical ambiguity, 'viticultural potentialities', 'viticultural zones', 'soil', 'viticultural environment' are often preferred to that of 'viticultur- al terroirs'. By employing the term 'viticultural zones' New World viticulture has attempted to avoid this dilemma. The comprehensive human facets of terroir are not always met in every vineyard in the world, particularly in the young producing countries. While the term 'viticultural zones' provides a relatively simple vineyard characterisation, that of 'terroir' is likely to require more features and, in any case, a more cautious approach. From a New World perspective, much emphasis has been placed on climate and rather scant attention paid to soil and its complex interaction with wine grapes (White, 2003). At the other extreme, 'terroir' has often been incorrectly associated with soil attributes at the expense of climatic factors. In reality, a spectrum of various scientific notions of 'terroir' exist, ranging from the very simple to the most complex (Vaudour, 2003). For example, a simple expression of 'terroir' might encompass only the soil or climate. A more complex one might integrate a wide range of factors, to include the following: vineyard soil, substrate lithology, the 'soil×climate' interaction, the viticultural agro-ecosystem (interaction of 'soil $\times$ climatexplant genotypes $\times$ training system $\times$ grape composition'), the wine-growing agro-ecosystem (interaction of 'soil $\times$ climatexplant genotypes $\times$ training system $\times$ grape composition $\times$ winemaking skills', as exemplified by Carbonneau, 2001, 2002, through the Viticultural Terroir Unit), and the historical and sociological wine-growing agro-ecosystem (Vaudour, 2003). The last-mentioned is considered closer to the familiar acceptance of 'terroir', which relies on the secular and the collective taste memory and experience of grape/wine 'typicité' (Letablier and Nicolas, 1994).

\section{The Diverse Aims of Viticultural Zoning}

The demarcation of registered designations of origin, appellations of origin or protected geographical indications is one of the most obvious of zoning aims. This practice, which originated as early as the XIX $^{\text {th }}$ century in Europe, is now widely applied in the relatively young wine-growing countries, such as South Africa, Canada, Australia and New Zealand. A registered designation of origin is a guarantee to the consumer that the product originates from an officially recognised district or region or the demarcated viticultural area. As a minimum requirement, a designation of origin usually admits $85 \%$ or as high as $100 \%$ of the harvest from the designated territory or stipulates that the wine be made from $100 \%$ grapes grown in the stated area. Other stringent requirements may include common production rules, such as specified varieties and training modes, maximum yield threshold, minimum sugar content at harvest, and minimum planting density, all of which together are likely to favour the similarity of the final products between different winemakers within the territory. It should be noted that only twenty countries, including France, Italy, Portugal, Hungary, Slovaquia, Bulgaria and the Czech Republic, ratified the Lisbon Agreement (1958) on the protection of appellations of origin and their international registration. The appellation of origin concept relies on the existence of terroirs, that is to say, demarcated appellation areas that may contain one or more specific terroir units.

In some geographical indications, such as the American Viticultural Areas (AVA) and the Chilean 'Appellation of Origin', the guarantee of a unique origin is still not given for $100 \%$ of the harvest used to make the certified wine. Also, there are no common production rules imposed by law. Conversely, both the French 'Appellation d'Origine Contrôlée' (AOC) and the Italian 
'Denominazione di Origine Controllata e Garantita' (DOCG) have the strictest designation systems in the world, as they include a sensory control of final products, in addition to viticultural production rules. However, no matter what production rules are in place, designation of origin and geographical indications are intended to ensure the correct designation of the region and variety on the bottle label. The practice may ultimately result in higher prices for consumers and the creation of 'elite' vineyards.

How does one circumscribe or delineate protected viticultural areas? According to past practices, demarcation relies frequently on pre-existing district, commune or plot boundaries, which have to be assigned to a class defined by a unique qualitative variable comprising three modalities (the third modality being optional) (Vaudour, 2003): i) belongs to the defined viticultural area; ii) does not belong to the defined viticultural area; iii) could belong to the defined viticultural area provided certain conditions are satisfied. The assignment criteria for AOC demarcation have often been: (i) historical (based variously on customs and anteriority) or (ii) physical (based on the geological or physiographic features). Other criteria may be based on prominent boundaries formed by the hydrological network, topography, road network or climatic factors. The assignment of historical criteria may be regarded as empirical, but, paradoxically, the so-called environment-modelled terroirs that lack any anteriority of viticultural use and common production rules do not wholly fit the familiar acceptance and notion of terroir.

There are other important zoning aims apart from the aim concerned with protecting a production territory from usurpation of its geographical name. For example, in numerous vineyard regions, the boundaries are already fixed as registered designation of origin or geographical indication areas. However, often these are rough administrative boundaries that are not appropriate for the technical management of the winegrowing space. It may be necessary to segment the geographical indication territory into homogeneous units for pest management, re-allocation of land, vineyard restructuring operations, grape harvest quality management, or site selection for new vineyards. For instance, by identifying locations where either lime-induced Fe chlorosis or drought or excessive wetness occurs, and is tolerated by resistant vines, overall can aid in the selection of suitable plant material. In fact, it was the search for resilient plant material that prompted one of the first attempts at viticultural zoning; in 1887, Pierre Viala, on behalf of the French Ministry of Agriculture, sought to find native vines resistant to calcareous soils. Later on, with the support of the American botanist T. Munson, Viala found lands with high calcium carbonate in central Texas and the vigorous native vines growing there (Legros, 1996). In particular, V. Berlandieri, V. Cinerea and V. Cordifolia have since been used as chlorosis-resistant rootstocks. Furthermore, in re-allocation of land and vineyard restructuring operations it may be necessary to first characterise or delineate the sites in order to determine whether they are favourable to either variety changes or training mode changes. These viticultural activities raise a number of questions, which are common to most zonings, regarding site suitability and site capability assessment, such as: i) where are the most suitable sites located for certain selected varieties? ii) where are the best sites located for production of an acid- and sugar-rich harvest? iii) which are the best terroirs for making fine wines? Each of these questions leads to different output maps.
The first question relates to the search for areas that correspond to high, moderate, low or no suitability for a given grape variety or a given rootstock. The spatial units are then ranked by the degree of suitability, as was done in Oltrepó Pavese for the Barbera, Croatina, Riesling italico, Pinot noir or Chardonnay cultivars (Scienza et al., 1990), or in Anjou for the cultivar Cabernet franc based on index of 'precocity' (Barbeau et al., 1998), or based on various suitability indexes for several rootstocks, such as Riparia, 101-14, 3309C, SO4, Gravesac, 5BB, 1103P, 110R, Rupestris (Morlat, 2001).

The second question pertains to the choice of the areas that are likely to improve or facilitate grape harvest assemblage in a viticultural space. This leads ultimately to the creation of capability maps of vineyard areas. Capability maps are common in precision viticulture and seldom cover areas larger than a few hectares. Fig. 1 gives an example of a capability map for the Southern Côtes-duRhône, resulting from the intersection of a potential terroir unit map and the harvest maturity data from 67 plots with Grenache noir, covering a period of 17 years (Vaudour, 2001 and 2003).

The third question concerns the hierarchy of vineyard areas ranging from the best to the worst, where the aim is to establish an elite production system. The capability classes are derived from a series of quantitative and environmental/ecophysiological criteria as in the case of the Ribera del Duero (Spain). Here Sotés et al. (1994) used 14 environmental criteria that included the following: soil water content, soil depth, active $\mathrm{CaCO}_{3}$, organic matter content of surface horizon, cation-exchange capacity, $\mathrm{K}$ content, texture of B horizon, substrate lithology, elevation, slope angle, drainage conditions and waterlogging, the presence of other lithofacies and zones with mixed substrates. Such viticultural zoning is seldom carried out due to the large number of variables for which data are seldom available, difficulty in ranking them and the complexity of the analyses.

Site selection of new vineyards encompasses all zoning aims. In addition to the environmental characterisation of the site, other aims may be related to the choice of suitable plant material, training modes and viticultural techniques. In new areas, the lack of empirical viticultural data may lead to inaccurate site determination. In comparison, where the data have been in existence for some time in the long-standing traditional viticultural regions and where the terroirs have always been renowned for their fine wines, the site selection process is less challenging. In the case of Australia, the choice of suitable varieties and viticultural techniques tend to be guided by those adopted in European vineyards that are endowed with similar environmental conditions (homoclimes). This is referred to as a 'homoclime approach' by Dry and Smart (1988).

Another important aim related to viticultural zoning is to facilitate the management of wine production at the various spatial levels, and scale transfer between them (see Fig. 2). This implies the consideration of the map scale, spatial resolution and the level of analysis (Girard and Girard, 2003).

Lastly, by attempting to address the issue of terroir sustainability, viticultural zoning can be aimed at soil conservation through an assessment of the risk of erosion, as exemplified in the Penedès-Anoia vineyard region (Martínez-Casasnovas and Sánchez-Bosch, 2000). 


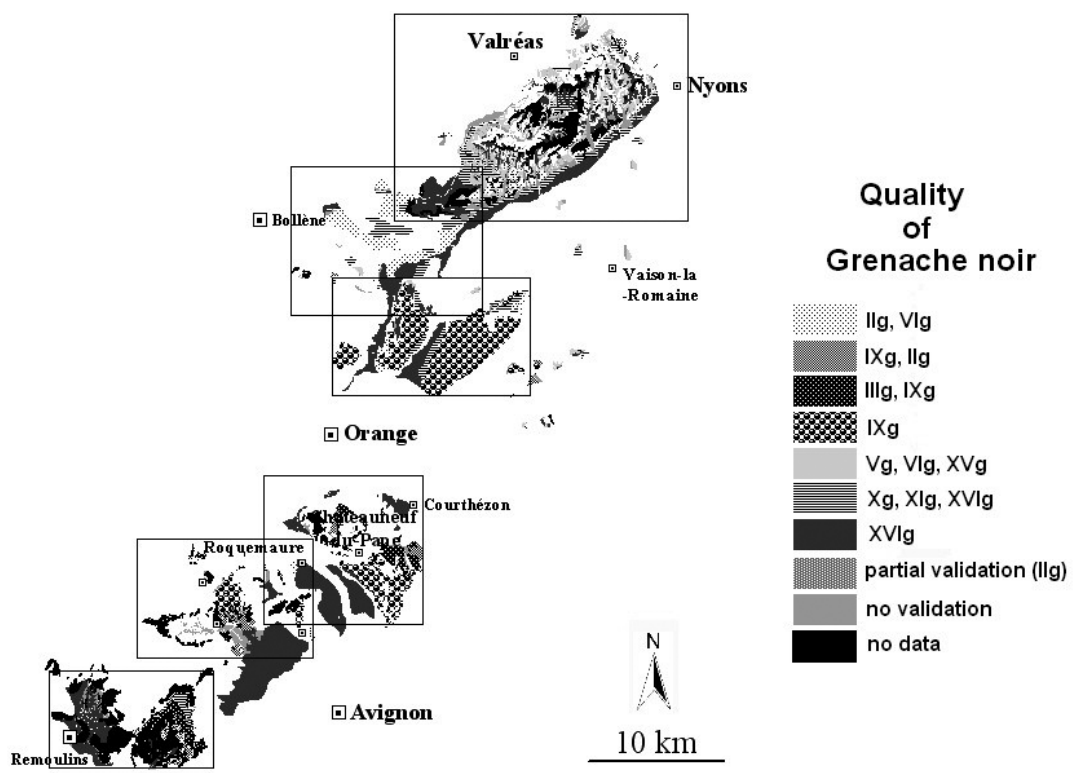

FIGURE 1

Capability map for Grenache noir harvest over the Southern Côtes-du-Rhône (from Vaudour, 2003). The Roman letters correspond to harvest quality groups obtained from multivariate clustering of harvest maturity variables. The harvest quality groups mentioned are the most frequent in each terroir unit over a 17-year series. Modalities threshold values of harvest maturity variables are given in Vaudour, 2003. IIg, high to very high sugar content (expressed as estimated degree, Deg), pH, "estimated degree/titratable acidity" rate (Deg/A), low titratable acidity (A), late harvest, big berries; IIIg, high to very high Deg, pH, Deg/A, low A, early harvest, big berries; Vg, high to very high Deg, moderate $\mathrm{pH}$, Deg/A, high A, big berries; VIg, high to very high Deg, low pH, moderate to low Deg/A, high to very high A, small berries; IXg, moderate Deg, high to very high $\mathrm{pH}$, low A, high Deg/A, early harvest, very big berries; Xg, moderate to low Deg, moderate $\mathrm{pH}$, low Deg/A, high A, very big berries; XIg, moderate to low Deg, moderate $\mathrm{pH}$, moderate Deg/A, moderate A, big berries; XVIg, low Deg, pH, Deg/A, very high A, late harvest, very big berries.

\section{Main wine-producing regions and countries involved in zon- ing studies}

It is only in recent years that viticultural zoning has begun to gain international importance. An important milestone is the resolution VITI 2/93 that emerged from the General Assembly of the OIV (International Organization of Vine and Wine) that requested member countries and international organisations to: 1) promote research in scientific methods in order to characterise and delimit homogenous viticultural zones (without major human intervention) that are capable of yielding original vitivinicultural products of quality, and 2) apply suitable methods of research and interpretation that consider all the factors of the viticultural ecosystem including the soil and climatic characteristics, interactions between variety and site and the effects of the human factors on the maturation and the quality of the grape. In this way, the OIV has attempted to create an international terroir-zoning group.

\section{Traditional Wine Producing Countries}

Most traditional wine producing countries of the Old World, such as France, Italy, Spain, and Germany, have been involved in zoning studies for some time. These countries have demarcated viticultural designation areas in all regions over spatial scales that range from less than 1 ha to more than 200000 ha in area. In France (the number one wine producing, exporting, importing and consuming country in 2000), some of the earliest terroir-related studies actually emerged in the 1930s at the same time as the creation of the AOC (Appellation d'Origine Contrôlée), and focused on vine and wine on behalf of the French National Board of
Appellations of Origin (Institut National des Appellations d'Origine, INAO). Post-phylloxera reconstruction of renowned inherited wine districts needed to justify the influence of geographic origin on the quality of wines on some objective basis. Included among the various French regions concerned with zoning studies, many of which have been initiated since the 1970s, are principally Bordeaux (Seguin, 1986; Van Leeuwen et al., 1989), the Languedoc (Bonfils, 1980; Astruc et al., 1980; Carbonneau, 2000), the Loire Valley (Morlat, 1989; Barbeau et al., 1998; Morlat, 2001), Alsace (Party et al., 1990; Lebon, 1993), Champagne (Dolédec, 1995), the Côtes-du-Rhône (Vaudour et al., 1998; Vaudour, 2001, 2003), and Cognac (Cam et al., 2003). However, Alsace, comprising nearly 14600 hectares, is the only French region in which the terroirs have been mapped entirely (Party et al., 1990). Since the mid-XIX ${ }^{\text {th }}$ century, both the University of Bordeaux (Faculty of Enology) and the Viticulture Department of the Agricultural Engineering, Institute of Montpellier (so-called 'Agro-Montpellier' today), have played a leading role in viticultural zoning. Furthermore, a large number of open-minded and resolute vinegrowers and wine professionals have financed several zoning works. Other institutions, such as the Viticultural Research Centre INRA-URVV of Angers, have examined many facets of the "terroir/vine/wine" system, while others such as the Institut National Agronomique Paris-Grignon have dealt with a wide range of cartographic issues pertaining to viticultural zoning. Commencing in the 1990s in Italy, the Piedmont, Lombardy, Trentino, Tuscany regions conducted several zoning studies that focused on the adaptation and functioning of vine vari- 


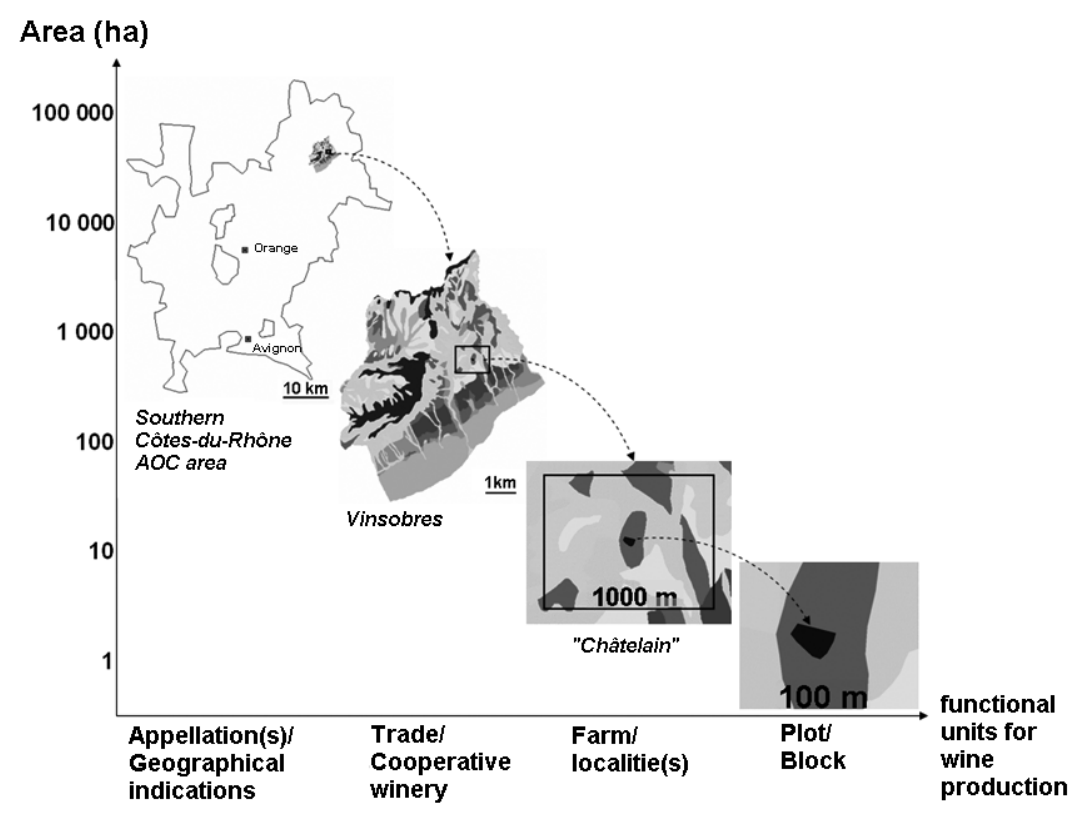

FIGURE 2

Main stepped spatial levels for viticultural zoning (after Vaudour, 2003).

eties (viticultural 'vocations'). These studies were facilitated by various role-players: the Viticulture Department of the Catholic University of Piacenza, the University of Milan (Istituto de Cultivazione Arboree), the Istituto Agrario of San Michele all'Adige (Trentino) and the Istituto Sperimentale per lo Studio e la Difesa del Suolo of Florence (Falcetti et al., 1997). Also, in the early 1990s in Spain, the Escuela Technica Superior de Ingenieros Agronomos of the Madrid Polytechnic University surveyed the viticultural suitability of several regions, including the Ribera del Duero, Duero, La Mancha, Rueda and Toro (Sotés et al., 1994). The Agricultural Chemistry Faculty of the University of Seville also undertook several studies on Andalusian designations of origin, including Jerez-Xérès-Sherry (Paneque et al., 2002). Other studies examined the geographical differentiation of island sites based on sensory analysis for Majorca (Mulet et al., 1992) and the Canary Islands (Gutierrez-Afonso y Yanes-Marrero, 2002). Commencing in the 1970s, in Germany, studies on environmental site characterisation were undertaken in the Rheingau and Sudbade vineyards (Becker, 1989).

Generally, European terroir-related studies tend to rely on the available data pertaining to both the vine/wine response and the vineyard environment. They often stress the influence of the soil on terroir (Vaudour et al., 2005). Terroir cartography has been developed at all scales, especially since the 1990s following the widespread use of geomatics.

\section{Young Wine Producing Countries}

In the New World, the Viticulture Department of the University of California, together with Californian wine professionals, performed several zoning studies based on the 'degree-days' concept developed by Amerine and Winkler (1944). This prominent study specified five viticultural regions or zones with respect to their ripening ability and influence on grape quality, based on the average accumulated degree-days of the growing season. In the absence of a long history of acquired skills, experience and familiarity with the natural environment of the vineyards, the New World viticulture tended to rely on the technical approach in delimiting zones for new vineyards. In recent years, viticulture has seen phenomenal growth worldwide, particularly in countries such as Australia, New Zealand, the United States, Canada, Chile, and South Africa. Simultaneously, there are several examples of terroir-related studies that commenced in the 1970s, in California (Noble, 1979; Guinard and Cliff, 1987), in the Four Corners Region (Dutt et al., 1981), and in South Africa's Western Cape (Saayman, 1977) and the Stellenbosch District (Carey et al., 2003). Moreover, site characterisation and/or zone surveying are now being initiated in most of the young wine producing countries, including New Zealand (Tesic, 2002), Canada (Shaw, 1999), Australia (Bramley and Lamb, 2003), Chile (Parra and Vaudour, 2004), Brazil, Argentina and Uruguay. The importance of soil to the vine and wine quality is gaining recognition in New World viticulture as in South African (Saayman, 1977, 1992) and Australian (Northcote, 1988; White, 2003). Nonetheless, there is still a tendency in terroir-related studies to emphasise the importance of the climatic attributes of the vineyard environment (Gladstones, 1992) relative to those of the soil.

\section{ZONING MATERIALS AND METHODS}

The homogeneous units obtained through viticultural zoning are frequently referred to as 'terroirs'. However, the spatial scale and physical attributes, along with the materials, methods and assumptions used, may differ significantly according to the preference of the author and attributes of the vine-growing region and, consequently, inter-regional and especially international comparisons are often difficult to make. 


\section{Geographical Differentiation of Vineyard Zoning Materials}

It is possible to divide viticultural zoning studies into two main groups on the basis of the zoning materials employed. On the one hand, there are those studies that stress the geographical differentiation of wines, grapes, or grapevine characteristics as the basis for zoning and, on the other hand, there are those studies that focus on the geographical differentiation of land capabilities or vineyard suitability. The latter group uses a range of soil characteristics and climatic factors as key variables, but with varying degrees of significance (Vaudour, 2002). In the case of the first group, the geographical differentiation of wines, grapes, or grapevine characteristics derived from results obtained from experimental plots or commercial wineries has been widely demonstrated using physiochemical analysis and/or sensory analysis, as in California (e.g., Noble, 1979; Guinard and Cliff, 1987) and Europe (Mulet et al., 1992; Fischer et al., 1999; Carbonneau, 2000). However, in many of these studies, the sites or wineries are often roughly spatially referenced and/or the environment poorly defined. Moreover, the numbers of representative sample-sites or wineries are often inadequate to accurately demarcate the sensory/chemical zones boundaries or those relating to the grape/wine quality. Thus, most zoning studies that deal with geographical differentiation of grapes and wines either focus on the understanding of plant ecophysiological functioning at the local scale or attempt to map the land capabilities or vineyard suitability using various spatialised environmental variables. Data on sensory/physio-chemical analyses may be introduced but only after the representative sites have been fully characterised within terroir units, as in the case of the Loire Valley (Brossaud et al., 1998).

\section{The Varied Scales of Viticultural Zoning Studies}

In spite of the diversity of terroir-related scientific studies, researchers have paid very little attention to the spatial modelling of terroir and issues related to the spatial scale (Vaudour, 2002). Over the past three decades, most terroir-related scientific studies have focused mainly on the plant or plot (or subplot/block) level through a network of experimental sites. These local-level approaches have examined the relationships between the physiochemical and sensorial qualities of wine and the degree of grape maturation, along with selected soil and climatic characteristics, by careful monitoring of these parameters, as in the Bordeaux Region (Seguin, 1986), California (Noble, 1979), the Loire Valley (Morlat, 1989), Trentino (Falcetti and Scienza, 1991), Alsace (Lebon, 1993), and the Rheingau (Fisher et al., 1999). Traditionally, these local-level approaches have used data based primarily on point source measurements. Except in the case of the Loire Valley (Morlat, 2001) no other attempts have been made to broaden the scale of analysis or to validate the results on a larger scale.

Other spatial-oriented approaches to zoning have involved the characterisation of the geographical patterns of the land, usually at the regional scale (Bonfils, 1980; Astruc et al., 1980; Party et al., 1990; Dolédec, 1995; Sotés et al., 1997; Vaudour et al., 1998; Vaudour, 2001; Carey, 2001; Cam et al., 2003). However, the extensiveness of study areas examined, usually over 10000 ha, and the lack of supporting viticultural data seldom allow these regional approaches to be validated.

Recently, the widespread use of geomatics has enabled terroir units to be characterised at a wide range of spatial scales.
Geomatics includes a set of methodological approaches and data acquisition systems such as Geographic Information Systems (GIS), Global Positioning System (GPS) and digital imaging (satellite and aerial), along with several processing and interpretation methods. All can be employed in some respect in the analysis of terroir units, ranging in scale from the smallest field plot through to the farm level and up to as large as the continental or global level. In zoning studies, it is important to consider several of these levels together. Firstly, the field level should be examined to understand some viticultural situations so as to probe further into an understanding of the relationship of "whole plant-berry" development (Deloire et al., 2002) to certain intrinsic environmental components of the terroir unit, such as light exposure and the temperature and the moisture levels within the canopy and bunch zone. In this way, the vintner may influence the quality of the harvest and the 'typicité' of the wine. Zoning at larger scales is more suited to professional or managerial needs of a viticultural district (see Fig. 2), but still requires the use of data from the sample sites at the field level.

There are three organisational or spatial levels which stem from climatology and which are commonly referred to in grapevine research: (i) the 'macro' or regional scale (from tens to hundreds of kilometres), (ii) the 'mesoscale' for a topographical unit or a block/vineyard (tens of metres up to kilometres) and (iii) the 'microscale' for the canopy (millimetres to metres). These levels may exhibit some ambiguity because their corresponding output map scale and spatial resolution are not strictly defined (Vaudour, 2003). For example, the microscale is sometimes confused with phytoscale or plant scale. A map scale higher than or equal to $1 / 25000$ is currently recommended for terroir zoning, so as to provide an adequate level of detail in monitoring the area under control of a winery or a vine-growing farm.

\section{Main Zoning Methods}

The simplest zoning method is that related to demarcating registration boundaries. It involves assigning a boundary to a preexisting one that has been accepted historically or customarily based on the distribution of a single qualitative variable. In demarcating registration boundaries, many local approaches may rely on boundaries that are spatially defined by the distribution of data related to some aspects of the climate, plant/grape or wine. Usually the data or observations are taken at a number of representative points that are then roughly interpolated within the existing boundaries. In such cases, discussion is focused on the causal relationships between the varied plant functional parameters of the terroir/grape/wine system (see Fig. 3), rather than their spatial validity.

The regional 'spatial' approaches are those likely to be utilised for determining map units that are graphically described by polygon areas circumscribed by boundaries, as in the case of choropleth maps. The soil survey is the most common basis for most terroir maps, resulting typically from so-called 'free survey' field approaches (Burrough, 1986; Legros, 1996). Many terroir studies in grapevine research are actually based on conventional pedological surveys with free sampling design (e.g., Costantini and Lizio-Bruno, 1996; Paneque et al., 2002) sometimes carried out over a reference soil region (Cam et al., 2003). The conceptual model of the 'basic terroir unit' (Unité Terroir de Base, UTB) as defined by Morlat (1989) was simplified through the "rock, alter- 


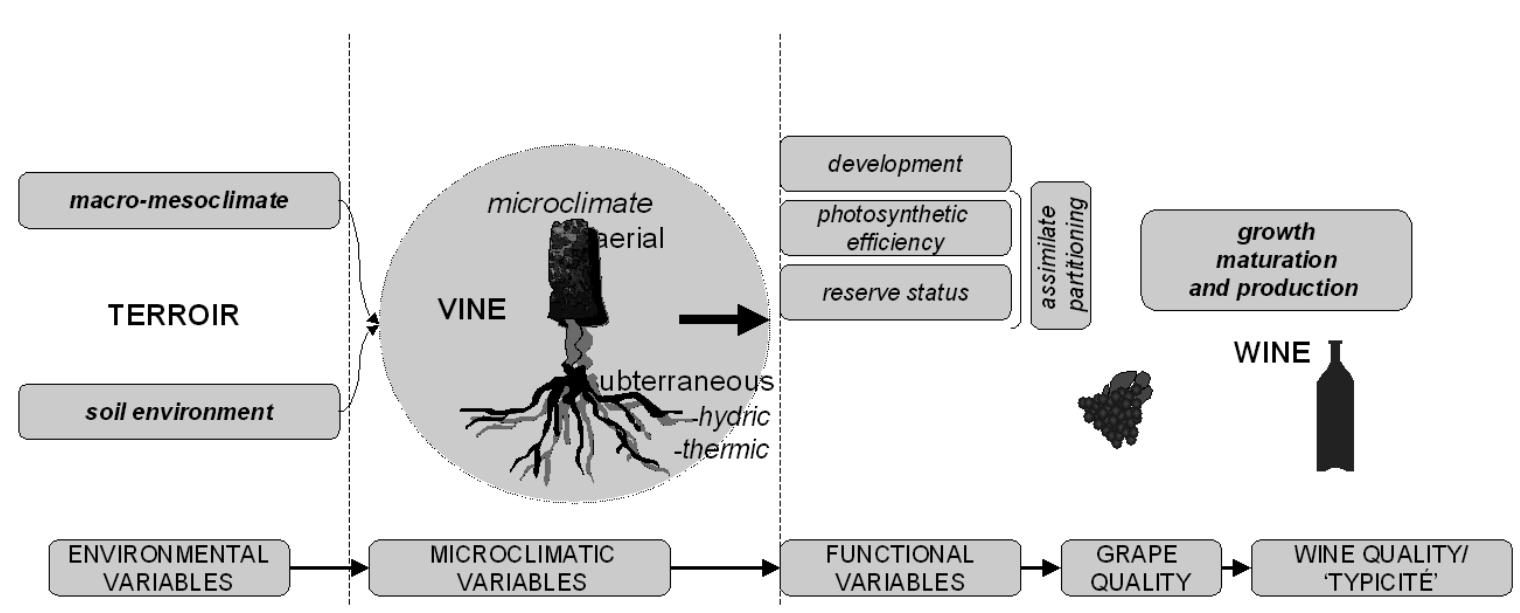

FIGURE 3

Chain representation of the "terroir/vine/wine" system (after Lebon, 1993).

ation, alterite" indicators trilogy (Morlat, 2001), derived from a geological free survey.

Other spatial approaches have created thematic maps (Legros, 1996) based on a variety of geographical databases, including that of the soil. Thematic maps can be based on a quantitative or mechanistic model, such as that created for the zoning of sugar content over the European Union (Riou et al., 1994) or created from a comprehensive viticultural database or from temperature and rainfall data for a network of weather stations. Thematic map design can also be based on several parametric criteria (Bonfils, 1980; Astruc et al., 1980; Sotés et al, 1994), however when parametric criteria are completely aggregated they are difficult to compare and rank; threshold values are not easy to assign and some criteria are likely to negate the importance of other criteria in the final analysis. Thematic map design can also combine various GIS-handled spatial models, either without any soil data (Laville, 1990), or integrating available soil maps (Dolédec, 1995; Carey, 2001; Vaudour, 2001, 2003).

All GIS-based terroir approaches face a number of challenges or are beset by several problems. Typically, the number of outputmodelled units is infinite, and therefore difficult or impossible to wholly validate given the limitation regarding the frequency and duration of the viticultural sampling scheme. Moreover, some output units may not correspond to any physiographic field reality likely to be experienced by the vine-growers, and therefore have to be either clustered or segmented. In cases where multiscale and multi-source data are used, there is a need for data integration that is not readily solved by computer methods. Consequently, the issue of information synthesis is at the very heart of the spatial modelling of terroir. A three-step method using satellite imagery as a tool for creating such a synthesis was proposed by Vaudour (2001, 2003): (i) firstly, a soil landscape conceptual model is built using field knowledge, satellite image processing, stereoscopic photograph examination, along with multiple topographical, geological and pedological maps, each soil landscape unit being described according to several environmental variables; (ii) secondly, the soil landscape units are aggregated into broader-scale potential terroir units from the environmental variables using cluster analysis, so as to limit the number of output units and enable viticultural validation, and (iii) thirdly, the potential terroir units are validated into terroir units across serial grape harvest quality clusters over the course of a long series of vintages (see Fig. 4).

\section{Trends In Zoning Methods}

Although the influences of the water regime and soil temperature on grape/wine quality are currently recognised (Seguin, 1986; Van Leeuwen et al., 1989; Morlat, 2001; White, 2003; Vaudour et al., 2005), knowledge of environmental influences in other areas is still fragmentary. With respect to the soil environment, the influences of moisture and temperature on the root system are often difficult to explore owing to its considerable depth, variable life duration and heterogeneous physical and chemical composition. Also, what is lacking in attempting to understand the various environmental influences is a common set of criteria that can be applied universally. There is a strong need, therefore, to develop a spatially defined generalisation of viticultural data in order that distinct vine environments can be compared worldwide. The multi-criteria climatic classification system for world viticulture suggested by Tonietto (1999), Tonietto and Carbonneau (2004), and referred to as 'geoviticulture' by Carbonneau and Tonietto (1998), is an attempt to address this problem. Similarly, the soil data system as described by the World FAO (ISSS, 1998) and the recent reference training systems developed by Carbonneau and Cargnello (2003) could contribute in the development of a global classification system.

Another related issue is the rationalisation of both the criteria and the zoning methods worldwide. This goal may be more difficult to achieve since it depends on the availability of geographical data that are not often obtained by the same methods. The availability of climatic and viticultural data at various spatial 


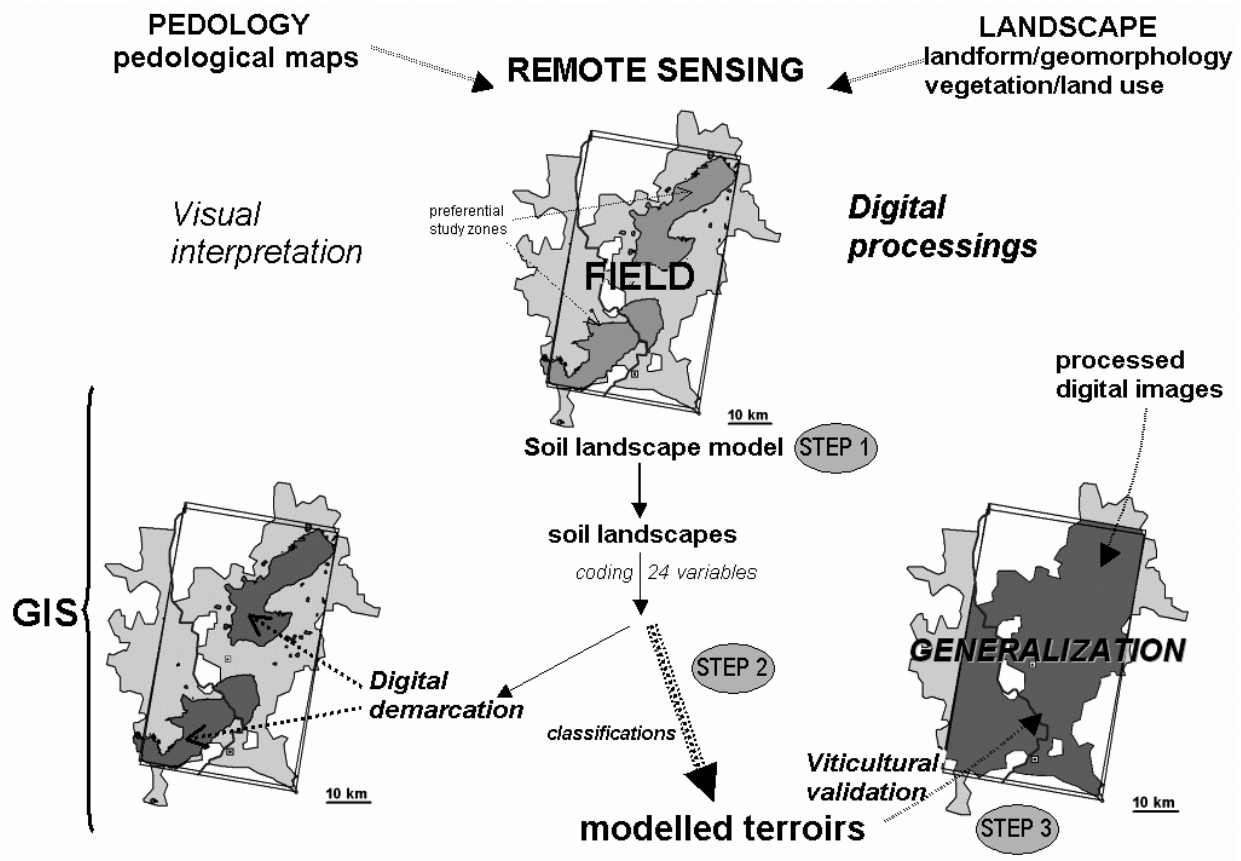

FIGURE 4

Spatial approach to terroir zoning by soil landscape modelling (after Vaudour, 2003).

scales over a sufficient series of vintages is especially a serious limitation in zoning studies. This is also a major limitation in the mapping of soil properties but less so for soil types.

Increasingly, the spatial approaches in viticultural zoning are being challenged by the use of high-resolution mapping. Since vintage 1999, when the first commercially available grape yield monitor came onto the market, it has been possible for grapegrowers and winemakers to acquire detailed geo-referenced information about vineyard performance (Bramley and Lamb, 2003). The high-resolution data (from decimetres to a few metres) obtained from precision viticulture together with geostatistics can be used to define quality zones at a very detailed map scale (more than 1/10 000) so as to enable selective harvesting according to different yield/quality criteria. It is thus necessary to know, according to Bramley and Lamb (2003): (i) whether the patterns of within-vineyard variation are constant from year to year; (ii) whether patterns in yield variations are matched by patterns in quality variations; (iii) what are the key drivers of vineyard variation and whether these can be managed; and (iv) finally, whether targeting individual management problems is more economically beneficial than conventional uniform management. The answers to these questions will require significant improvements in areas related to vineyard soil survey (increase in soil map polygon purity), especially measurements of the soil electric resistivity, elevation modelling, targeted ground sampling, and remote sensing techniques.

Recent studies on detailed block zoning have employed satellitebased remote sensing data in the visible and near infrared spectral bands of the electromagnetic spectrum. Using $4 \mathrm{~m}$-resolution
IKONOS satellite images, one study monitored the vineyard canopies for the purpose of deriving the NDVI index (Normalised Difference Vegetation Index) and its relationship to the LAI (Leaf Area Index) so as to estimate vine vigour (Johnson, 2003; Johnson et al., 2003). A similar study was undertaken using $25 \mathrm{~cm}$-resolution aerial images (Hall et al., 2003). Other studies examined the soil surface variability using aerial photographs (Wassenaar et al., 2001) and 4 m-resolution IKONOS and 2.5 m-resolution supermode SPOT satellite images (Parra and Vaudour, 2004). With further research, hyperspectral remote sensing data from other parts of the spectrum may also prove useful in block zoning.

\section{CONCLUSIONS}

In recent years, viticultural zoning has assumed a greater degree of importance, encouraged by worldwide efforts to produce wines of distinct quality for the highly competitive and diverse markets at the national and international levels. As such, most studies on viticultural zoning have sought to improve some aspect related to the grape/wine quality, the growing environment or the financial situation of the wine-grower. The diversity of zoning aims has arisen from various territorial directives, economic interests, and the expressed needs of potential users at several levels within the wine-production system. The demarcation of registered designations of origin or protected geographical indications is considered the most important zoning aim. Although many zoning studies appear to have a common set of objectives, the spatial scale of analysis, materials, methodological approaches and underlying assumptions employed are highly diverse. Consequently, comparing the results from different countries and regions is often problematic. There is a strong need therefore, to develop a spa- 
tially defined generalisation of viticultural data and methodological approaches in order that distinct vine environments can be globally compared. Viticultural zoning is not synonymous with terroir zoning, but it subsumes many facets associated with the familiar notion and acceptance of terroir. Zoning approaches may also differ in their context in which the aim is to demonstrate either the specificity and 'typicité' of wines derived from the long established traditions of small family wineries or to optimise production and management of industrial-style chameleon wines in order to satisfy today's average consumer.

\section{LITERATURE CITED}

Amerine, M.A. \& Winkler, A.J., 1944. Composition and quality of musts and wines of California grapes. Hilgardia 15, 493-675.

Astruc, H., Héritier, J. \& Jacquinet, J.C., 1980. Zonage des potentialités viticoles du département de l'Aude. Prog. Agric. Vitic. 15/16, 296-320.

Barbeau, G., Morlat R., Asselin, C., Jacquet, A. \& Pinard, C., 1998. Comportement du cépage Cabernet-Franc dans différents terroirs du Val de Loire. Incidence de la précocité sur la composition de la vendange en année climatique normale (exemple de 1988). J. Int. Sci. Vigne Vin 32, 69-81.

Becker, N.J., 1989. Zum Einfluß der Standortfaktoren auf Menge und Güte der Erträge. Die Wein-Wissenschaft 44, 25-42.

Bohmrich, M., 1996. Terroir: competing perspectives on the roles of soil, climate and people. J.Wine Res. 7, 1-33.

Bonfils, P., 1980. Sols, cartographie, contraintes du milieu viticole méditerranéen. La restructuration du vignoble et ses problèmes. Bull. A.F.E.S. 2, 109-123.

Bramley, R.G.V. \& Lamb, D.W., 2003. Making sense of vineyard variability in Australia. In: Ortega, R. \& Esser, A. (eds). Precision viticulture. Proceedings of an international symposium held as part of the IX Congreso LatinoAmericano de Viticultura y Enologia, Chile. Centro de Agricultura de Precisión. Pontificia Universidad Católica de Chile. Santiago, Chile. pp. 35-54.

Brossaud, F., Cheynier, V., Asselin, C. \& Moutounet, M., 1998. Influence du terroir sur la composition en flavonoïdes des baies et des vins de Cabernet franc en Val de Loire. Incidences sur la typologie sensorielle des vins. Bull. O.I.V. 811$812,757-771$

Burrough, P.A., 1986. Principles of Geographical Information Systems for Land Resources Assessment. Clarendon Press, Oxford.

Cam, C., Vital, P., Fort, J.L., Lagacherie, P. \& Morlat, R., 2003. Un zonage viticole appliqué, basé sur la méthode des secteurs de référence, en vignoble de Cognac (France). Etude et Gestion des Sols 10, 35-42.

Carbonneau A., 2000. Climat et sol : critères d'évaluation et effets sur le comportement de la vigne. In: V. Sotés (ed.). Proc. $3^{\circ}$ Simp. Int. «Zonificación vitivinícola », May 2000, Tenerife (Spain). CD-ROM.

Carbonneau, A., 2001. Concepts "terroir". In : Groupe Européen d'Etude des Systèmes de Conduite de la vigne (GESCO) (Ed.). Proc. XIIèmes Journées du GESCO, 3-7 July 2001, Montpellier (France), 2, p. 669.

Carbonneau A., 2002. Méthodes de zonage relatives à la plante. Une introduction. In : Proc. $4^{\circ}$ Int. Symp. «Viticultural zoning », June 2002, Avignon (France). http://symposium.monaoc.com

Carbonneau, A. \& Cargnello, G., 2003. Architectures de la vigne et systèmes de conduite. Dunod, Paris.

Carbonneau, A. \& Tonietto, J., 1998. La Géoviticulture - de la géographie viticole aux évolutions climatiques et technologiques à l'échelle mondiale. Revue des Enologues 87, 16-18.

Carey, V.A., 2001. Spatial characterisation of natural terroir units for viticulture in the Bottelaryberg-Simonsberg-Helderberg winegrowing area. MSc Thesis, Stellenbosch University, Stellenbosch, South Africa.

Carey, V.A., Bonnardot, V. \& Knight, F., 2003. The zoning of terroirs for wine production: South Africa. In: Fregoni, M., Schuster, D., Paoletti, A. (eds). Terroir, zonazione, viticoltura, Phytoline. $26 \mathrm{pp}$.

Costantini, E.A.C. \& Lizio-Bruno, F., 1996. I suoli del comprensorio vitivinicolo di Montepulciano. Le loro caratteristiche, gli ambienti, i caratteri funzionali per la produzione del Vino Nobile di Montepulciano. In : Giunta regionale. Vino Nobile di Montepulciano : zonazione e valorizzazione del territorio, Regione Toscana, Giunta regionale, Florence. pp. 47 - 74.

Deloire, A., Lopez, F. \& Carbonneau, A., 2002. Réponses de la vigne et terroir. Eléments pour une méthode d'étude. Prog. Agric. Vitic. 119, 78-86.

Dolédec, A.F., 1995. Recherche des composantes principales des terroirs viticoles afin d'élaborer un outil d'aide à la gestion au moyen d'observatoires et de traitements statistiques de données spatialisées. Application au vignoble champenois $\mathrm{PhD}$ Thesis, Institut National Agronomique Paris-Grignon, 16, rue Claude Bernard, 75005 Paris, France.

Dry, P.R. \& Smart, R.E., 1988. Vineyard site selection. In: Coombe, B.G. \& Dry, P.R.. Viticulture, tome I. Winetitles, Adelaide. pp. 190 - 204.

Falcetti, M., 1994. Le terroir : qu'est-ce qu'un terroir ? Pourquoi l'étudier ? Pourquoi l'enseigner ?. Bulletin de l'O.I.V. 757-758, 245-275.

Falcetti, M., Bogoni, M., Campostrini, F. \& Scienza, A., 1997. Gestire il territorio con la zonazione : le experienze nel vigneto Italia. Vignevini 1/2, 50-61.

Falcetti, M. \& Scienza, A., 1991. Utilisation de l'analyse sensorielle comme instrument d'évaluation des choix viticoles. Application pour déterminer les sites aptes à la culture du cépage Chardonnay pour la production de vins mousseux en Trentin. Bull. O.I.V. 26, 13-23.

Fischer, U., Roth, D. \& Christmann, M., 1999. The impact of geographic origin vintage and wine estate on sensory properties of Vitis vinifera cv. Riesling wines. Food Quality and Preference 10, 4-5, 281-288.

Girard, M.C. \& Girard, C.M., 2003. Processing of remote sensing data. Balkema publishers, Rotterdam.

Gladstones, J., 1992. Viticulture and environment. Winetitles, Adelaide.

Guinard, J.X. \& Cliff, M., 1987. Descriptive analysis of Pinot noir wines from Carneros, Napa and Sonoma. Am. J. Enol. Vitic. 30, 214-217.

Gutiérrez Afonso V.L. \& Yanes Marrero C., 2002. Caracterización sensorial preliminar de los vinos tintos de la Isla de Tenerife (Islas Canarias, España). In: V. Sotés (Ed.). Proc. $3^{\circ}$ Simp. Int. «Zonificación vitivinícola », May 2000, Tenerife (Spain). CD-ROM.

Hall, A., Louis, J. \& Lamb, D., 2003. Characterising and mapping vineyard canopy using high-spatial-resolution aerial multispectral images. Computers \& Geosciences 29, 813-822.

Hancock, J.M., 1999. Terroir: the role of geology, climate, and culture in the making of French wines by James E. Wilson. Feature review. J. Wine Res. 10, 1, 43-49.

International Society of Soil Science (ISSS), 1998. World Reference Base for Soil Resources. 84 World Soil Resources Report. FAO, ISRIC and ISSS, Rome.

Johnson, L.F., 2003. Temporal stability of an NDVI-LAI relationship in a Napa Valley vineyard. Australian Journal of Grape and Wine Research 9, 96-101.

Johnson, L.F., Roczen, D.E., Youkhana, S.K., Nemani, R.R. \& Bosch, D.F., 2003 Mapping vineyard leaf area with multispectral satellite imagery. Computers and Electronics in Agriculture 38, 33-44.

Laville, P., 1990. Le terroir, un concept indispensable à l'élaboration et à la protection des appellations d'origine comme à la gestion des vignobles : le cas de la France. Bull. OIV 709-710, 217-241.

Lebon, E., 1993. De l'influence des facteurs pédo- et mésoclimatiques sur le comportement de la vigne et les caractéristiques du raisin. Application à l'établissement de critères de zonage des potentialités qualitatives en vignoble à climat semi-continental (Alsace). PhD Thesis, Dijon University, Dijon, France.

Legros, J.P., 1996. Cartographies des sols. De l'analyse spatiale à la gestion des territoires. Presses Polytechniques et Universitaires Romandes, Lausanne.

Letablier, M. H. \& Nicolas, F. 1994. Genèse de la «typicité ». Sci. Alim. 14, 5, 541 556.

Martínez-Casasnovas, J.A. \& Sánchez-Bosch, I., 2000. Impact assessment of changes in land use/conservation practices on soil erosion in the Penedès-Anoia vineyard region (NE Spain). Soil \& Tillage Res. 57, 101-106.

Morlat, R. (coord.), 2001. Terroirs viticoles: étude et valorisation. Oenoplurimédia, Chaintré.

Morlat, R., 1989. Le terroir viticole: contribution à l'étude de sa caractérisation et de son influence sur les vins. Application aux vignobles rouges de la Moyenne Vallée de la Loire. PhD Thesis, University of Bordeaux II, Bordeaux, France. 
Mulet, A., Berna, A. \& Forcén, M, 1992. Differentiation and grouping characteristics of varietal grape musts and wines from Majorcan origin. Am. J. Enol. Vitic. 43, 221-226.

Noble, A.C., 1979. Evaluation of Chardonnay wines obtained from sites with different soil compositions. Am. J. Enol. Vitic. 30, 214-217.

Northcote, K.H., 1988. Soils and Australian viticulture. In: Coombe, B.G. \& Dry, P.R. Viticulture, tome I. Winetitles, Adelaide. pp. 61 - 90.

Paneque, G., Roca, M., Espino, C., Pardo, C., Aldecoa, J. \& Paneque, P., 2002. The 'albarizas' and the viticultural zoning of Jerez-Xérès-Sherry and ManzanillaSanlúcar de Barrameda registered apellations of origin (Cadiz, Spain). In: V. Sotés (ed.). Proc. $3^{\circ}$ Simp. Int. «Zonificación vitivinícola », May 2000, Tenerife (Spain). CD-ROM.

Parra, P. \& Vaudour, E., 2004. Contribution of very high resolution satellite remote sensing to the mapping of harvest zones in the Maipo Valley (Chile). In: SASEV/SAWWV. Proc. $28^{\text {th }}$ Int. Conference on viticultural zoning, November 2004, Cape Town (South Africa). CD-ROM.

Party, J.P., Duchaufour, H., Revol, P. \& Thaler, A., 1990. Les unités de paysage et les sols du vignoble alsacien. Cartographie au 1/25 000ème. GIE Sol Conseil, Association pour la Relance Agronomique en Alsace, Comité Interprofessionnel du Vin d'Alsace (eds). Private report. Strasbourg-Colmar, France.

Riou, C. \& Carbonneau, A., 1994. Le déterminisme climatique de la maturation du raisin: application au zonage de la teneur en sucre dans la communauté européenne. Ed. Commission des communautés européennes, EUR15863, Luxembourg.

Salette, J., Asselin, C. \& Morlat, R., 1998. Le lien du terroir au produit: analyse du système terroir-vigne-vin; possibilité d'applications à d'autres produits. Science des Aliments 18, 251-265.

Saayman, D, 1977. The effect of soil and climate on wine quality. In: Int. Sym. Quality of the vintage. February 1977. Cape Town, South Africa. pp 197 - 206.

Saayman D, 1992. Natural influences and wine quality Part 2. The role of soil. Wynboer, August, 49-51.

Scienza, A., Bogoni, M, Valenti, L., Brancadoro, L. \& Romano, F.A., 1990. La conoscenza dei rapporti tra vitigno ed ambiente quale strumento programmatorio in viticoltura: stima della vocazionalità viticola dell'Oltrepò Pavese. Vignevini 12, 4-62.

Seguin, G., 1986. 'Terroirs' and pedology of wine growing. Experientia, Birkhäuser-Verlag Basel, 42, 861-872.

Shaw, A.B., 1999. The emerging cool climate wine regions of eastern Canada. J. Wine Res. 10, 79-94.

Sotés, V., Gómez-Miguel, V. \& Gómez-Sanchez, P., 1997. Caractérisation du terroir en Espagne : méthodologie de l'évaluation et de la validation. In: INRA
Angers-Montpellier (Eds). 1 ${ }^{\text {er }}$ Coll. Int. "Les Terroirs Viticoles", July 1996, Angers, France. pp. 43 - 51.

Sotés, V., Gómez-Sanchez, P., Laya, H., \& Gómez-Miguel, V., 1994 Cuantificación de las variables implicadas en la delimitación y caracterización de zonas vitícolas en la D.O Ribera del Duero. In: 7th GESCO, 21-23 July 1994, Valladolid, Spain. pp. 248-256.

Tesic, D., 2002. Environmental effects on Cabernet-Sauvignon (Vitis vinifera L.) when grown in different sub-regions within Hawke's Bay (New Zealand). PhD Thesis, Massey University, Palmerston North, New Zealand.

Tonietto, J., 1999. Les macroclimats viticoles mondiaux et l'influence du mésoclimat sur la typicité de la Syrah et du Muscat de Hambourg dans le Sud de la France. Méthodologie de caractérisation. PhD Thesis, ENSA-M., 2 place Viala 34000 Montpellier, France.

Tonietto, J. \& Carbonneau, A., 2004. A multicriteria climatic classification system for grape-growing regions worldwide. Agricultural and Forest Meteorology 124, $1-2,81-97$.

Van Leeuwen, C., Baudet, D., Duteau, J., Seguin, G. \& Wilbert, J., 1989. Les sols viticoles et leur répartition à Saint-Emilion, Pomerol et quelques autres communes du Libournais, Connaissance de la Vigne et du Vin 23, 131-150.

Vaudour, E., 2001. Les terroirs viticoles. Analyse spatiale et relation avec la qualité du raisin. Application au vignoble AOC des Côtes-du-Rhône méridionales. $\mathrm{PhD}$ Thesis, Institut National Agronomique Paris-Grignon, 16, rue Claude Bernard, 75005 Paris, France.

Vaudour, E., 2002. The quality of grapes and wine in relation to geography: notions of terroir at various scales. Journal of Wine Research 13, 117-141.

Vaudour, E., 2003. Les terroirs viticoles. Définitions, caractérisation et protection. Dunod, Paris.

Vaudour, E., Girard, M.C., Brémond, L.M. \& Lurton, L., 1998. Caractérisation spatiale et constitution des raisins en AOC Côtes-du-Rhône méridionales (Bassin de Nyons-Valréas). J. Int. Sci. Vigne Vin 32, 4, 169-182.

Vaudour, E., Morlat, R., Van Leeuwen, C \& Delédec, A.F., 2005. Terroirs viticoles et sols. In: Girard, M.C., Walter, C., Rémy, J.C., Berthelin, J., Morel, J.L (eds). Sols et Environnement, Dunod, Paris. pp. 105-126.

Wassenaar, T., Baret, F., Robbez-Masson, J.M. \& Andrieux, P., 2001. Sunlit soil surface extraction from remotely sensed imagery of perennial, discontinuous crop areas; the case of Mediterranean vineyards. Agronomie 21, 235-245.

Wilson, J.E., 1998. Terroir. The role of geology, climate and culture in the making if French wines. University of California Press, Berkeley.

White, R.E., 2003. Soils for fine wines. Oxford University Press, New York. 